\title{
Clerodendrum inerme (L.) Gaertn. Extract Exerts Anticancer Activity on Lung Cancer Cells
}

\section{Mahendra Kumar Chouhan ${ }^{1,2}$, Pramod J ayadevappa Hurakadle ${ }^{1}$ and Harsha Vasudev Hegde ${ }^{3}$}

\author{
${ }^{1}$ Department of Pharmaceutical Biotechnology, College of Pharmacy, KLE Academy of Higher Education and \\ Research (Deemed-to-be University) Belagavi, Karnataka, India \\ ${ }^{2}$ Dr. Prabhakar Kore Basic Science Research Center, KLE Academy of Higher Education and Research \\ (Deemed-to-be University), Belagavi, Karnataka, India \\ ${ }^{3}$ ICMR- National Institute of Traditional Medicine (Formerly Regional Medical Research Center), Belagavi \\ Karnataka, India
}

(Received: June 12, 2018; Accepted: August 3, 2018; Published (web): December 10, 2018)

\begin{abstract}
Cancer is the leading cause of death word wide. Recently there are no new drugs for safe and efficient treatment. Clerodendrum inerme (L.) Gaertn. (Verbenaceae) plant is being used by the ethnic people for cancer treatment. In this study, cytotoxic and antiproliferative potential of hydroalcoholic (methanol and water; $70: 30 \mathrm{v} / \mathrm{v}$ ) extract of $C$. inerme were evaluated. Various anticancer investigations performed like, lung cancer cell A-549 culture, dye exclusion assay, MTT assay, morphological changes and compatibility with RBC, confirmed the presence of the moiety that have the cytotoxic and antiproliferative potential. Compatibility with RBC was observed, when treated with standard drug doxorubicin, and hydroalcoholic extract of $C$. inerme at $259.5 \mu \mathrm{g} / \mathrm{ml}$ concentration $\left(\mathrm{IC}_{50}\right)$. In addition, the same treatment reveled, decrease in cytotoxic efficacy and cell viability against lung cancer cells. Furthermore, change in the cell morphology also suggesting potent antitumor properties of $C$. inerme.
\end{abstract}

Key words: Clerodendrum inerme, RBC aggregation, MTT, Cytotoxicity.

\section{INTRODUCTION}

As per WHO statistics cancer is the leading cause of death. Every year, millions death occurr due to its recurrence and other contributing factors like age, genetic abnormalities and family history. ${ }^{1}$ Plant derived drugs like camptothecin, taxanes, etoposide, vincristine are important medicines that have potent anticancer activity. ${ }^{2}$ Conventional and traditional medicines are also used widely as complementary or alternative medicines ${ }^{3}$, also to cure this deadly disease, surgical removal, chemotherapy and radiotherapy are most of the time not adequate or effective to overcome. ${ }^{4}$ Traditional medicine system like Ayurveda, Siddha, Unani, Homeopathy and other

Correspondence to: Mahendra Kumar Chouhan E-mail: <mahendrachouhan.nbh@gmail.com> Tel: +91-8553229251

Dhaka Univ. J. Pharm. Sci. 17(2): 191-196, 2018 (December) DOI: http://dx.doi.org/10.3329/dujps.v17i2.39175 systems (Folk practices) of medicine were based on most of plant derived medicines. In the large section of the population, plant based traditional systems of medicine playing a vital role to provide health care which increasing the over harvesting of natural products. Traditional systems of medicines are playing in important role to meet the global health care burden. ${ }^{5}$ The richest source of medicinal value and their enormous potential medicinal plants are used for phenolic compounds, flavonoids, alkaloid, terpenoids, vitamins, tannins etc.. Secondary metabolites are interest of herbal-based medicines in over the globe. ${ }^{6}$ In case of new medicines, plant derivatives and metabolites have a significant place for preparation of drugs. ${ }^{7} \quad$ Naturally available sources are the hot topic and to identify the normal secondary metabolites is the intensive research topic now days. ${ }^{8} C$. inerme reacts on DNA and cause the 
fragmentation by some signaling pathways, in this context this study has been designed. The present study is focused on the effect of $C$. inerme extract on Lung cancer A-549 cell line to evaluate the DNA damage and their effect as anticancer agents. $C$. inerme plant belongs to family Verbenaceae, and plants belong to this family, have various useful ethnomedicinal properties. ${ }^{9}$ This plant is used as an ethnomedicine to treat cough, scrofulous infection, buboes problem, venereal infection, skin diseases, vermifuge and in beriberi. ${ }^{10} \mathrm{C}$. inerme plant contains some important phytoconstituents viz. pentadecanoic acid- $\beta$-D-glicoside, stigmasterol, $4 \alpha$-methyl-24 $\beta$ ethyl-5 $\alpha$-cholesta-14, 25-dien-3 $\beta$-ol, $\quad 24 \beta$-ethylcholesta-5,9(11),22-trien-3 $\beta$-ol,betulinicacid. ${ }^{11,12}$

These constituents have potential effects towards cancer cure. $^{13}$ The plant extract have shown significant cytotoxic activity ( $\left.\mathrm{LC}_{50}<100 \mathrm{ppm}\right)$. The extract was lethal to the brine shrimp at the concentration of $\mathrm{LC}_{50}<100 \mathrm{ppm}$.

\section{MATERIALS AND METHODS}

Collection of plant material and extract preparation. The $C$. inerme plant aerial parts were collected from Dandeli-Anshi forest, the North Karnataka region in the month of January, and authenticated by taxonomist Dr. Harsha V. Hegde, Scientist D Regional Medical Research Centre, (ICMR-RMRC), Belagavi, Karnataka with herbarium specimen no RMRC-1272. Plant material was shed dried and crushed, subjected to maceration process, $(70: 30 \mathrm{v} / \mathrm{v}$ in methanol and water). The extract concentrated using rotary evaporator and dried using hot air oven at $40^{\circ} \mathrm{C}$.

Phytochemical investigation. Phytochemical investigation for carbohydrates, proteins, amino acids, steroids terpenoids, glycosides, flavonoids, alkaloids, tannins, phenolic compounds, fat, oil, and saponins showed the presence of these moieties. ${ }^{2}$

\section{In vitro cytotoxicity activity}

Cell line and cell culture. The A-549 Lung cancer cells were procured from NCCS Pune, Maharastra, INDIA. The cells were cultured in T-75 cell culture flask using DMEM (Gibco, Invitrogen,
USA) medium, with $10 \%$ fetal bovine serum (FBS) (Gibco, Invitrogen, USA) penicillin-streptomycin 100 units (Gibco, Invitrogen, USA); gentamycin and amphoterecin (Himedia, India) at $\mathrm{pH} 7.4,37^{\circ} \mathrm{C}$ and air: $\mathrm{CO}_{2}$ (95: 5) condition in incubator (New Brunswick Scientific, Germany). ${ }^{14}$

Trypan blue dye exclusion assay. The A-549 Lung cancer cells were cultured at the density of $6 \times 10^{3}$ cells $/ \mathrm{ml}$.. The A-549 lung cancer cells were used when reached in exponential phase. The trypan blue dye exclusion assay was implemented to evaluate the number of viable cells present in the cultured cell suspension. Trypsinized cells were counted using neubaur chamber under an inverted light microscope (Labomed Inc., USA) cells were dyed using trypan blue, which is vital dye, live cells cell wall does not allow to enter the dye inside and the dead cells are differntiated by blue in color. ${ }^{15}$

MTT assay. The antiproliferative potential was evaluated using MTT (3-(4,5 dimethylthiazole-2-yi)2,5-diphenyl tetrazolium bromide) assay. The yellow MTT, a dark purple colored formazone, which is produced by reaction with mitochondrial succinate dehydrogenase was anoted by colorimetric analysis. Hydro-alcoholic extract of $C$. inerme on antiproliferative activity was determined by MTT assay, A-549 cells were seeded into 96 well plate (Corning, Cell bind, U.S.A.). The density of cells was $6 \times 10^{3}$ cells per well with $150 \mu \mathrm{l}$ of DMEM growth medium, 10\% FBS (Gibco, Invitrogen, USA) and penicillin-streptomycin (Invitrogen, USA). The plate was kept for incubation at $37^{\circ} \mathrm{C}, 5 \% \mathrm{CO}_{2}$ in a humidified incubator for $24 \mathrm{hrs}$. After the incubation, cells were treated in triplicates with test $C$. inerme extract in various concentrations of 1000, 500, 250, $125,62.5,31.25,15.625 \mu \mathrm{g} / \mathrm{ml}$ concentration for 24 hrs at $\mathrm{pH} 7.4$, temperature $37^{\circ} \mathrm{C}, 5 \% \mathrm{CO}_{2}$, in the incubator. Doxorubicin was used as the positive control. After $24 \mathrm{hrs}$ incubation, 20 $\mu \mathrm{l}$ MTT reagent at concentration $5 \mathrm{mg} / \mathrm{ml}$, pH 7.4 was added in each well, and kept in the dark for another $4 \mathrm{hrs}$ for fomazone crystal formation (color reaction). After 4 hrs. to stop the reaction and solubilize the formazone crystals, $100 \mu$ of DMSO (SIGMA-ALDRICH) was 
added to each well. The absorbance was measured at $630 \mathrm{~nm}$ on Elisa plate reader (Lisa 300, Germany) and the $\%$ cell viability were calculated using the formula. The dose response curve was plotted to determine $50 \%$ inhibition of cancer cells at inhibitory concentration $\mathrm{IC}_{50}$ values for plant extract and doxorubicin. ${ }^{16,17}$

$\%$ Cell viability $=\frac{\text { Absorbance of test }}{\text { Absorbance of negative control }} \times 100$

Change in cellular morphology. The A-549 lung cancer cells were analyzed for the change in morphology. Cells were treated for $24 \mathrm{hrs}$ at $\mathrm{IC}_{50}$ values of $C$. inerme extract and standard drug doxorubicin which shows the changes in the cell morphology, attached and detached cells due to the effect of inhibitory concentration by using inverted microscope at $40 \times{ }^{18}$

Erythrocyte aggregation assay. An equal volume of fresh blood, PBS and $10 \mathrm{mM}$ EDTA were added and centrifuged at $3000 \mathrm{rpm}$ for $10 \mathrm{~min}$ at $37^{\circ} \mathrm{C}$. The obtained erythrocytes pellet was washed in PBS twice. The fresh erythrocytes and plant extract were mixed at 1:1 ratios which were incubated at $37^{\circ} \mathrm{C}$ for $1 \mathrm{hr}$. After incubation of samples, slides were prepared and imaging were taken, by using contrast imaging inverted microscope (Labomed, USA). ${ }^{19}$

Statistical analysis. Data were expressed as mean \pm standard deviation, transform data and nonlinear regression analysis, using GraphPad Prism ${ }^{\circledR}$ version 5.01, GraphPad software, San Diego, California, USA.

\section{RESULTS AND DISCUSSION}

Extract preparation and phytochemical screening. Arial part of $C$. inerme were identified and shed dried plant material was subjected to crush and macerate in methanol and water at 70: 30 ratio for three days with occasional stirring, further extract was filtered through whatman filter paper no 1 . Further solvent was evaporated using rota vapor instrument and dried in a temperature controlled hot air oven to dry extract. The yield from $100 \mathrm{~g}$ plant material was $1.84 \mathrm{~g}$ extract. The extract was brown in color and hygroscopic in nature. The extract was stored in airtight container at $2-8{ }^{\circ} \mathrm{C}$ in refrigerator.

Phytochemical screening showed the presence of carbohydrate, protein, amino acid, steroids, triterpenoids, glycosides, flavonoids, alkaloids, tannins, phenolic compounds, and saponins in the aerial part hydroalcoholic extract of $C$. inerme. ${ }^{2}$

Trypan blue dye exclusion assay. The A-549 Lung cancer cells were cultured in a culture T flask. Cells were counted using neubaur chamber under an inverted light microscope. Cells were dyed using trypan blue, which is vital dye, live cells cell wall does not allow to enter the dye inside and the dead cells are differntiated by blue in color, the average number of differentiated live cells in per $\mathrm{ml}$ were counted and $6 \times 10^{3}$ cells per $\mathrm{ml}$ accordingly were prepared for seed in 96 well plate.

MTT assay. The cell toxicity assay is one of the vital determinant for toxicity analysis, which explain the proliferation response to any anticancer agent and provide the information for survival, metabolic activity and cell death. ${ }^{20}$ Recently, it has been reported that $C$. inerme have potent antiproliferative activity on liquid tumors also. ${ }^{2}$ Earlier studies have demonstrated that $C$. inerme have chemical moiety, have anticancer effect in dose dependent manner which was evaluated in the present study using different extract and cell line. ${ }^{21}$ In-vitro cytotoxic activity against A-549 lung cancer cell line was evaluated against different concentration of hydro alcoholic extract of $C$. inerme and doxorubicin in a dose dependent manner. As shown in figure 1 the $\mathrm{IC}_{50}$ values were $259.5 \mu \mathrm{g} / \mathrm{ml}$ and $88.05 \mu \mathrm{g} / \mathrm{ml}$ for hydro-alcoholic extract of $C$. inerme and doxorubicin, respectively when treated for a period of 24 hrs. Since we observed the marked effect on treatment, therefore the results demonstrated that hydro-alcoholic extract of $C$. inerme has time and dose dependent antiproliferative activity on lung cancer cell lines, which showed the sensitivity of cells to plant extract, that showing the strongly 
support its promising results to cancer treatment by Ayurvedic physicians.

Change in cellular morphology. A-549 lung cancer cells were seeded in 24 well plate and observed for cellular morphological changes using inverted microscope at 40x after $24 \mathrm{hrs}$ treatments of untreated and treated with plant extract and standard drug doxorubicin at $\mathrm{IC}_{50}$ values. The change in cellular morphology is presented in figure 2 in which (A) represents the untreated normal morphology of A-549 lung cancer cells, (B) treated cells with $\mathrm{IC}_{50}$ of hydro alcoholic extract of $C$. inerme plant extract and (C) treated with standard drug doxorubicin treated cells. The different morphology, which showed the state of cancer cells, floating and rounded dead cells, detached from the surface of 24 well plate. Also attached cells loosing the growth and changing the shape of cells and the proliferation, which can be easily understood by microscopic visualization. When cells were treated with anticancer drug, results showed similar effect that support the previous study pattern. ${ }^{22}$

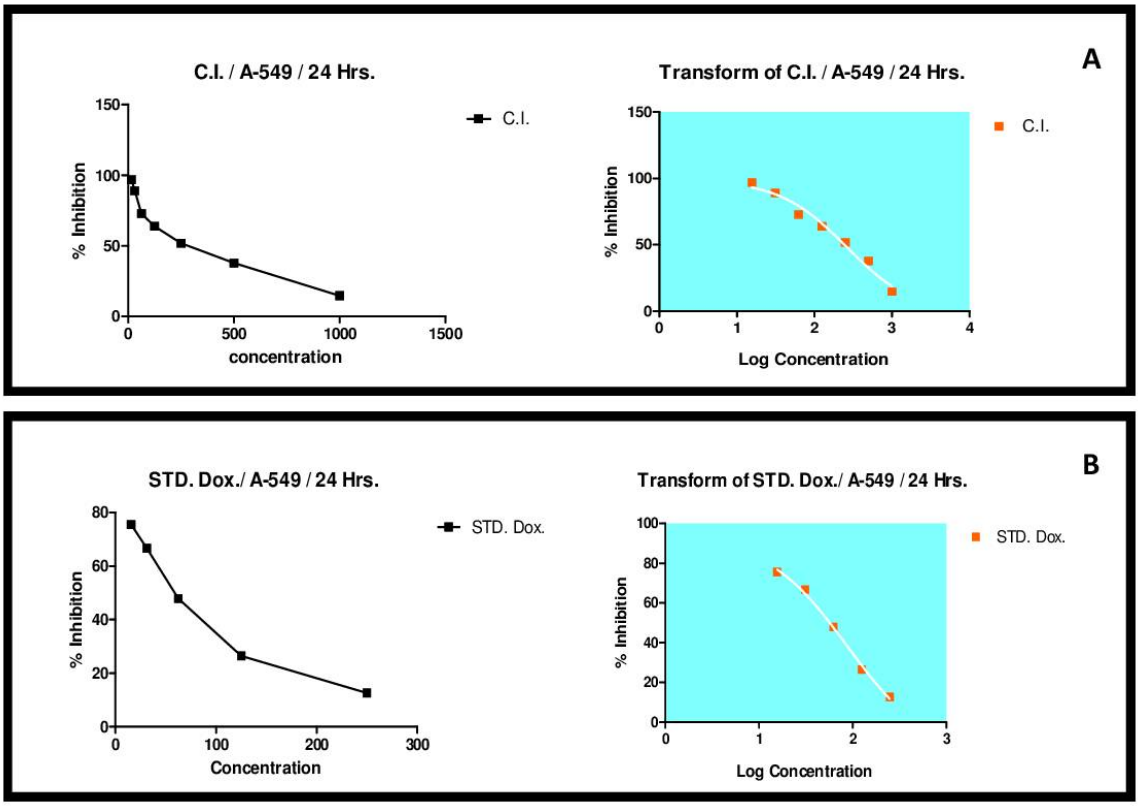

Figure 1. Cytotoxic effect on human lung cancer cell line A-549, graphs represents the percentage inhibition at different concentration (A) treatment with $C$. inerme, (B) treatment with doxorubicin, data were expressed as mean \pm standard deviation.

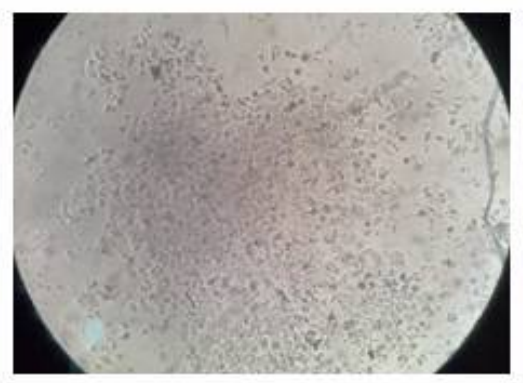

A

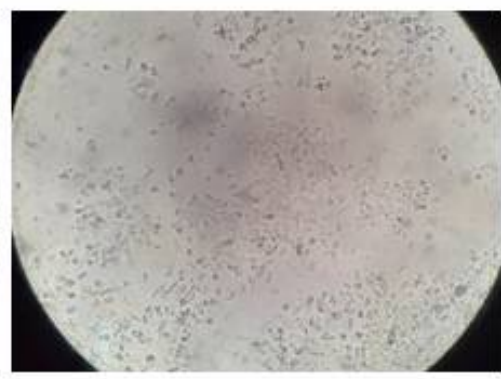

B

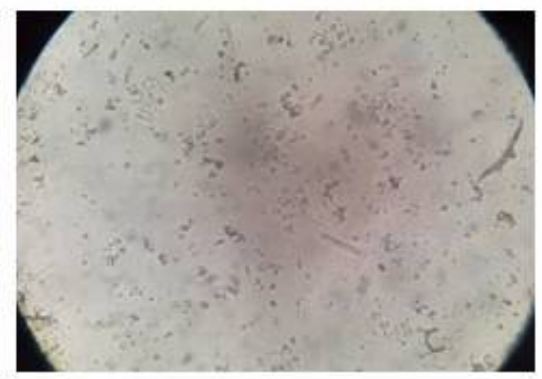

C

Figure 2. Represents the cellular morphology of A-549 lung cancer cells (A) Represents the untreated normal morphology of cells, (B) Cells were treated with $\mathrm{IC}_{50}$ concentration of $C$. inerme plant extract (C) Cells were treated with $\mathrm{IC}_{50}$ concentration of standard drug doxorubicin for $24 \mathrm{hrs}$. 
Toxicity analysis of plant extract on red blood cells. The interaction study of plant extract and doxorubicin with human blood components are highly desirable, a few numbers of studies that have been conducted so far indicate the potential for adverse effects at the cellular level, with susceptibilities in the circulatory and dermal systems. ${ }^{23}$ This can explain the damage on red blood cells (RBCs) and its interactions. In this investigation, it has assessed at the cellular level, the impact of plant extract on red blood cells (RBCs) for future application of the plant extract, which can be helpful for further investigations. In this method, the cellular impact of plant extract on red blood cells (RBCs) has been evaluated. The standard drug doxorubicin treatment at $\mathrm{IC}_{50}$, which does not course a significant aggregation of erythrocytes upon $1 \mathrm{~h}$ incubation at $37^{\circ} \mathrm{C}$, whereas the plant extract have showed less effect with the erythrocytes (Figure 3). These results clearly revealed that the plant extract elicit no toxic response as cellular clumping (aggregation), when compare with the standard drug treatment. ${ }^{24}$
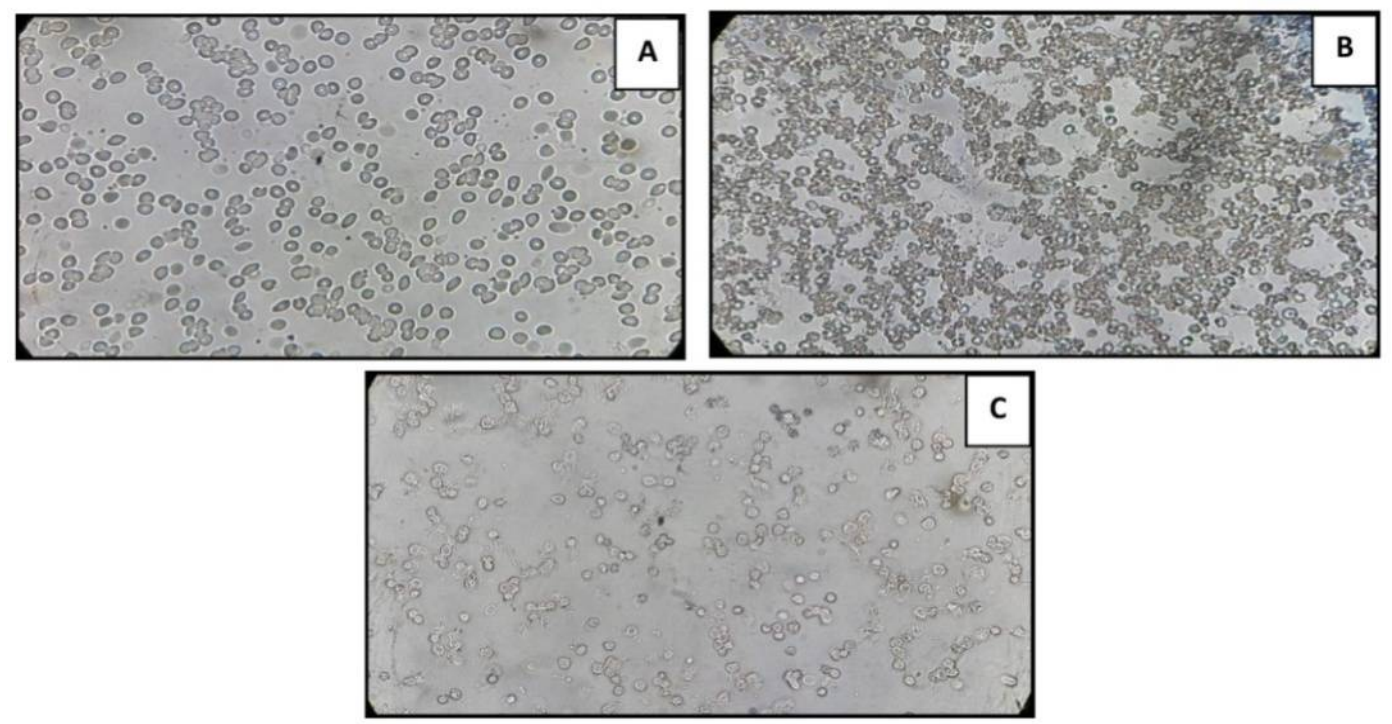

Figure 3. Microphotograph of RBC aggregation at 40X, (A) Untreated cells, (B) Treated with doxorubicin $\mathrm{IC}_{50}$ value, $(\mathrm{C})$ Treated with plant extract at $\mathrm{IC}_{50}$ value.

\section{CONCLUSION}

C. inerme is an indigenous plant which has been used in the folk medicine for many years. This study provides the scientific validation to its traditional medicinal claims. Cell based assays were used to determine the effectiveness of the test extract on cell proliferation to reveal the direct cytotoxic effect which lead to cell death. MTT assay helped to measure the binding to receptors and associated with a variety of signal transduction events which involved in various expression processes. The results cytotoxicity of $C$. inerme confirms the antiproliferative potential which reflects cytocompatibility with RBC, trypan blue dye exclusion assay, MTT assay, cellular morphological changes/ These confirms the previous study findings on the antiproliferative potential of the plant extract.

\section{REFERENCES}

1. World Health Organization. Cancer Fact Sheet N297. 2014. World Health Organization. p. 297. http://www.who. int/mediacentre/factsheets/fs297/en/ (linc assesed: 25/05/2018)

2. Chouhan, M.K., Hurkadle, P.J. and Hegde, H.V. 2017. Evaluation of Clerodendrum inerme (L.) Gaertn. on Burkitt's Lymphoma Cancer. Indian J. Pharm. Education Res. 52, 241-7.2. 
3. World Health Organization (WHO). WHO Traditional Medicine Strategy 2002-2005. World Health Organisation Geneva. http://www.wpro.who.int/health_technology/book_ who_traditional_medicine_strategy_2002_2005.pdf (linc assesed: 25/05/2018)

4. Upadhya, V., Hegde, H.V., Bhat, S. and Kholkute, S.D. 2014. Non-codified traditional medicine practices from Belgaum region in Southern India: present scenario. $J$. Ethnobiol Ethnomed. 10, 49. (http:// doi: 10.1186/17464269-10-49)

5. Khazir, J., Mir, B. A., Pilcher, L. and Riley, D. L. 2014. Role of plants in anticancer drug discovery. Phytochem. Lett. 7, 173-81.

6. Tyler, V. E. 1993. The honest herbal. A sensible guide to the use of herbs and related remedies. Pharmaceutical Products Press. New York, 1993.

7. Upadhya, V., Hegde, H.V., Bhat, S., Hurkadale, P.J., Kholkute, S. D. and Hegde, G. R. 2012. Ethnomedicinal plants used to treat bone fracture from North-Central Western Ghats of India. J. Ethnopharmacol. 142, 557-62.

8. Prakash, S. and Jain, A.K. 2011. Antifungal activity and preliminary phytochemical studies of leaf extract of Solanum nigrum Linn. Int. J. Pharm. Sci. 3, 352-5.

9. Fan, P. and Lou, H. 2004. Effects of polyphenols from grape seeds on oxidative damage to cellular DNA. Mol. Cell. Biochem. 267, 67-74.

10. Kiritikar, K. and Basu, B. 1987. Indian Medicinal Plants. Int B Distrib, p.1432-1436.

11. Shrivastava, N. and Patel, T. 2007. Clerodendrum and healthcare $\square$ : an overview. Med. Aromat. Plant Sci. Biotechnol. 1, 142-150.

12. Pandey, R., Verma, R.K. and Gupta, M.M. 2006. Pentadecanoic acid $\beta$ - D -glucoside from Clerodendrum inerme. Indian J. Chem. 45, 2161-3.

13. Pandey, R., Verma, R.K. and Gupta, M.M. 2007. Highperformance thin-layer chromatographic method for quantitative determination of $4 \alpha$-methyl-24 $\beta$-ethyl- $5 \alpha$ cholesta-14,25-dien-3ß-ol, $\quad 24 \beta$-ethylcholesta-5,9(11),22Etrien-3 $\beta$-ol, and betulinic acid in Clerodendrum inerme. $J$ Sep Sci. 30, 2086-91. (http://doi.wiley.com/10.1002/jssc. 200700073)

14 Dhamecha, D., Jalalpure, S. and Jadhav, K. 2016. Nepenthes khasiana mediated synthesis of stabilized gold nanoparticles: characterization and biocompatibility studies. J. Photochem. Photobiol. B: Biology. 154, 108-17.

15 Freshney, R.I. 2015. Culture of Animal Cells: A Manual of Basic Technique and Specialized Applications. John Wiley $\&$ Sons. Chapter 24, pp. 513-530.
16. Rajeshwari, H.R., Dhamecha, D., Jagwani, S., Patil, D., Hegde, S., Potdar, R., Metgud, R., Jalalpure, S., Roy, S., Jadhav, K. and Tiwari, N.K. 2017. Formulation of thermoreversible gel of cranberry juice concentrate: Evaluation, biocompatibility studies and its antimicrobial activity against periodontal pathogens. Materials Sci. Engineer. C. 75, 1506-14.

17 Riss, T. L., Moravec, R. A., Niles, A. L., Sittampalam, G. S., Coussens, N. P., and Brimacombe, K. 2013. Cell viability assays. Assay Guidance Manual. Bethesda (MD): Eli Lilly \& Company and the National Center for Advancing Translational Sciences. (https://www.ncbi.nlm.nih.gov/ books/NBK144065/?report=reader) (linc assesed: 05/02/ 2018)

18 Moacă, E. A., Farcaş, C., Ghițu, A., Coricovac, D., Popovici, R., Cărăba-Meiță, N. L., Ardelean, F., Antal, D. S., Dehelean, C. and Avram, Ş. 2018. A Comparative Study of Melissa officinalis Leaves and Stems Ethanolic Extracts in terms of Antioxidant, Cytotoxic, and Antiproliferative Potential. Evidence-Based Comple. Alternat. Med. 2018.

19. Kummara, S., Patil, M.B. and Uriah, T. 2016. Synthesis, characterization, biocompatible and anticancer activity of green and chemically synthesized silver nanoparticles-a comparative study. Biomed. Pharmacother. 84, 10-21.

20. AshaRani, P.V., Low Kah Mun, G., Hande, M.P. and Valiyaveettil, S. 2008. Cytotoxicity and genotoxicity of silver nanoparticles in human cells. ACS Nano 3, 279-290.

21. Al-Snafi, A.E. 2016. Chemical constituents and pharmacological effects of Clerodendrum inerme-A review. SMU Medical J. 3, 129-53.

22. Lombardi, V.R., Carrera, I. and Cacabelos, R. 2017. In Vitro Screening for Cytotoxic Activity of Herbal Extracts. Evidence-Based Comple. Alternat. Med. 2017. (https://doi.org/10.1155/2017/2675631)

23. Umoren, S.A., Obot, I.B. and Gasem Z.M. 2014. Green synthesis and characterization of silver nanoparticles using red apple (Malus domestica) fruit extract at room temperature, J. Mater. Environ. Sci. 5, 907-914.

24. Gurunathan, S., Kalishwaralal, K., Vaidyanathan, R., Venkataraman, D., Pandian, S.R.K., Muniyandi, J., Hariharan, N. and Eom, S.H. 2009. Biosynthesis, purification and characterization of silver nanoparticles using Escherichia coli. Colloids Surf. B: Biointer. 74, 328-335. 